\title{
The Possibilities of Using Empirical Methods in (Practical) Theology ${ }^{1}$ Jana Šídlová
}

\section{Introduction}

While I was working on and interpreting my first research project on empirical theology, which concerned the experience of young people with church community, I almost found myself in scientific confusion. My theological thinking and my own experience with the Church and the subject under discussion influenced the questions asked during the interviews, and also entered the analysis of these interviews. At the same time, the paradigm of my research methodology, in this case phenomenological sociology, forced me to completely forget my theology and ecclesial experience. A similar problem faces every theologian who decides to use the empirical method to research traditionally theological areas. Empirical methods can be used in a large variety of ways. The Dutch theologian Johannes van der Ven tried to unify these approaches and created paradigmatic models for practical theology he recognises as empirical. These are models of monodisciplinarity, multidisciplinarity, interdisciplinarity and intradisciplinarity. Each model presents a certain epistemological basis for how to work with empirical methods. ${ }^{2}$ Van der Ven then favours the last model and considers it the starting model for his conception of empirical theology. I believe that empirical methods within the intradisciplinarity model are not only usable in practical theology but can also be a challenge for systematic theology, which I will try to defend in this article. In an intradisciplinary model, we can both be the theologians and the empiricists without being in methodological contradiction.

First, I will introduce the outlines in which theology should work to be able to use empirical methods, and (following this) I introduce Van der Ven's models for practical theology. Then I will deal with the empirical methods themselves and explain which of these methods are suitable for theology. As a starting point for further theological exploration at this point, I then consider qualitative methods. Of those, ethnography is particularly important, where the personal role of the researcher plays the greatest role.

\section{Theology and Empirical Science: Conflict or Harmony?}

At first glance, it seems that theology and empirical sciences operate in two separate areas and do not need each other. According to K. Skalický, theology is born out of the need to understand the

This article is a part of the project of the specific research GAJU no. 157/2016/H.

2 Cf. Johannes van der VEN, Practical theology: an empirical approach, Leuven: Peeters, 1998, pp. 89-112. 
meaning of the world and our living there. This need is a response to existential anxiety that is typical to humans in extreme situations. K. Skalický talks about two horizons of thinking, each of which is characterised by one question. At first, we can ask, 'How far must the origin of the world be understood to make the world rationally explainable?' In the second, we ask, 'How far must the origin of the world be understood to make my life and the life of my group and of all people meaningful in the context of this world?'3 The first horizon he calls intellectual, the second existential, the latter being the starting point for his theology. ${ }^{4}$ The intellectual horizon looks at the world from the outside, from a certain point of view as a part of reality, and it is typical for natural and social sciences with their empirical methodology. The second approach seeks the meaning. It tries to understand the world as a whole; it is open to symbols, values and transcendence. From this point of view, there is an area of religion which is naturally present where the experience of faith has been made (the experience which anticipates the last sense). Theology, as a science, tries to reflect this sense rationally. ${ }^{5}$

It can be assumed that if we leave theology only in the existential horizon of rationality, we will greatly narrow its field of competence in favour of empirical sciences. Theological phenomena will then be explored by sociology or psychology (or eventually by religious studies) from their own perspective. K. Skalický supports this interdisciplinarity: his work is an example of an interdisciplinary approach. ${ }^{6}$ Social sciences, of course, have an inalienable right to this examination. The question is: If theology was completely separate from the field of intellectual rationality, could that cause some loss in its field? Is it not appropriate to unify individual approaches rather than to further divide them? Although theology is born out of the need to search for meaning and understanding, it belongs to both horizons. It is not only a science dealing with God or gods (taking into account the meaning of the word). ${ }^{7}$ If that was the case, empirical research would be impossible. The infinite and omnipotent God is indescribable. Still, you can believe in him and have a personal relationship with him through this belief. This is precisely why theology is a science of belief and practice of Christian faith ${ }^{8}$ Through such science, it is possible, subsequently, to talk about the transcendental and, at the same time, personal God. The subject of theology is the faith (witnessed by the Church) in the self-revelation of God in the person and the story of Jesus of Nazareth. The aim of this divine self-revelation is 'by which through Christ, the Word made flesh, man might in the Holy Spirit have access to the Father and come to share in the divine nature.' Faith takes place in man, in the Church, and in the context of society as a whole. It is necessary to examine all of its aspects, including those that are traditionally explored by social sciences. Why then could not theology use their methodology and work within their intellectual approach? Another reason why I consider theology as part of both horizons (or intellectual approaches) here is the relationship between theological ideas and Christian practice. Theology is not only a theo-

3 Cf. Karel ŘíHA, Fundamentální teologie v existenciálním horizontu myšlení, Studie 122-123/1989, p. 149. Available at: http://scriptum. cz/soubory/scriptum/studie/studie,_1989,_pp.122-123_in ocr.pdf, or also Karel SKALICKÝ, Po stopách neznámého Boha: náboženství a Bůh v novodobém religionistickém bádání, Praha: Aula, 1994, pp. 175-176.

4 František ŠTĚCH, Fundamentální teologie a křestanská identita, in: Církev a společnost: Karlovi Skalickému k 80. narozeninám, eds. František ŠTĚCH - Roman MÍČKA, České Budějovice: Jihočeská univerzita v Českých Budějovicích, Teologická fakulta, 2014, p. 30.

5 Cf. Karel ŘíHA, Fundamentální teologie..., p. 150.

6 Cf. František ŠTĚCH, Fundamentální teologie..., p. 31; Karel SKALICKÝ, Po stopách neznámého Boha... The whole book is devoted to different approaches to religion in individual disciplines.

7 Cf. František ŠTĚCH, Co je teologie, in: Domov jako Most. Festschrift kpadesátinám prof. Ivany Noble, Studies and texts of the Evangelical Theological Faculty, ed. Zdenko Š. ŠIRKA, Jihlava: Mlýn, 2016, p. 11.

8 Cf. Müller's definition in his textbook of dogmatics. Gerhard Ludwig MÜLLER, Dogmatika pro studium i pastoraci, Kostelní Vydří: Karmelitánské nakladatelství, 2010, p. 4.

9 Ibid. and Dei Verbum 2. 
retical science speaking from the heights above the Church and the world, it is also a science of confession and practice of Christian faith. The aim of theology is to keep theory and practice in balance. Christian practice and its reflection are inherently connected. For each theologian the practice of critical self-reflection (even the reflection of the practice of the whole Church) is very important. Here again, there is a place for empirical exploration of the practical dimension of the Christian faith as it manifests itself in man and his or her surrounding world.

The methods of empirical sciences can significantly enrich theology with the next horizon. In practical theology, this approach has been accepted a while ago and empirical methods and techniques have been used to research pastoral reality. This is related to the mutual relationship between social sciences and practical theology. This relationship at the theoretical and (later) at the practical level was dealt with by the Dutch theologian J. van der Ven, who also founded the first department of empirical theology in the European environment ${ }^{10}$ and played a very important role in introducing empirical methods into practical theology. ${ }^{11} \mathrm{He}$ is also one of the first theologians in the Roman Catholic tradition who have systematically devoted themselves to empirical methods. For this reason specifically, his epistemological point of view has been chosen in this article. Everyone who decides to explore reality in an empirical way has to deal with the choice of research ground. His models of the relation between empirical sciences and practical theology are the result of long-term research and they respond to most questions about mutual relations between practical theology and empirical sciences.

\section{Models of the Relation between Empirical Science and Practical Theology}

Van der Ven talks about four models of the relation between practical theology and empirical sciences, or their methods. These are monodisciplinary, multidisciplinary, interdisciplinary and intradisciplinary models. Each model embodies the way of how to approach empirical methods or how to work with them. His models are also chronologically sorted. It cannot be said that, except perhaps for the first one, any of the models were surpassed. Van der Ven, however, personally prefers the last model. This particular one creates a base for his concept of practical theology as empirical theology. ${ }^{12}$

\section{The Monodisciplinary Model}

This model considers practical theology as the applied science of systematic theology, and Van der Ven connects it with the period before the emergence of separate practical theology. In church practice, there have always been tools, instructions, and recommendations on how to apply theology into practice, and practical theology (as a separate discipline) takes this approach. As a university discipline, it began in our land thanks to Franz Stephan Rautenstrauch (the director of the Faculty of Theology in Prague) during the reign of Maria Theresa. ${ }^{13}$ Rautenstrauch (like

10 In the United States, development has been in another direction, which will not be addressed in this article. Cf. VEN, Practical theology..., pp. 2-8; Nancy FRANKENBERRY, Major Themes in Empirical Theology, in: Empirical Theology: A Handbook, ed. Randolph Crump MILLER, Religious Education Press, Birmingham, Alabama, 1992, pp. 340-380.

11 Some even claim that this role was paradigmatic. Cf. Richard R. OSMER, Johannes van der Ven's Contribution to the New Consensus in Practical Theology, in: Hermeneutics and empirical research in practical theology: the contribution of empirical theology by Johannes A. van der Ven, ed. C. A. M. HERMANS - Mary Elizabeth MOORE, Boston: Brill, 2004, p. 149.

12 The models were handled in accordance with J. van der Ven; in our environment those were (in abridged form) quoted by A. Křištan. Cf. Alois KŘIŠŤAN, Vztah pastorální teologie ke společenským vědám, in: Fórum pastorálních teologů, ed. Pavel AMBROS, Velehrad: Refugium Velehrad-Roma, 2000, specific pages are not mentioned, and VEN, Practical theology..., pp. 89-112.

13 Practical theology in our territory is called pastoral theology. Cf. Alois KŘIŠŤAN, Počátky pastorální teologie v českých zemích, Praha: Triton, 2004, p. 26. 
Schleiermacher in the Protestant environment) does not personally consider practical theology as a sublime discipline. If fact, they consider it very important to reflect pastoral practice as well as to move the discipline closer to systematic theology (Rautenstrauch) or historical theology (Schleiermacher). Van der Ven sees as the main problem the deductive approach that monodisciplinarity implies. It is characterised by applying eternal truths to a specific, up-to-date ecclesial and social situation that should not be too complex and heterogeneous. ${ }^{14}$ But is the situation in church and society in postmodern times simple and homogeneous? If fact, it is the exact opposite as one of the characteristics of our contemporary society is its diversity and ambiguity. ${ }^{15}$ The complexity of the Church and social situation is manifested especially in the process of ecclesial diversification and secularisation. These two phenomena represent other reasons why the monodisciplinary model should be rejected.

One comes to an inevitable conclusion that, in the present situation, there cannot be a standard model showing how to apply theological truths into practice. The current social, religious and pastoral situation is not uniform. Therefore, it is necessary to reject the deductive approach which contains the concept of applied theology. This specific type of theology needs an inductive approach to deal with the ambiguous, multivariable, even chaotic situation in the society and the Church. ${ }^{16}$

\section{The Multidisciplinary Model}

The need for a methodologically accurate description of a particular pastoral situation in the Church and society has been requested by many representatives of the theology of liberation since the $1960 \mathrm{~s}^{17}$ and also, for example, by E. Schillebeeckx. Practical theology should, according to them, take over the results of empirical research conducted in the social sciences and give them a theological insight and interpretation. This approach, therefore, involves a two-phase process. In the first stage, the theologian collects the results of empirical research related to his practical theme and, in the second one, he reflects on the data. This involves the attempt to relate this data to appropriate theological criteria and summarise them from a normative-theological perspective. In the Czech environment, Michael Martinek's Lost Generation may be an example of this approach. The author tries to make a theological interpretation of sociological and partly psychological research carried out on Czech youth. He uses practical and theological criteria for interpretation and proposes specific pastoral solutions for described situations and phenomena. ${ }^{18}$

The use of this is also advocated in the German Handbuch der Pastoraltheologie (1964).${ }^{19}$ Rahner introduces the term 'auxiliary sciences'. By these he means the social sciences, which are (according to him) the subject of theology. Theology does not have its own method for the empirical analysis of practice, nor is it competent to create such methods. Thus, it is relevant and important

14 The deductive approach seems to be surpassed even in the area of religious pedagogy, where it has prevailed for a long time. Cf. Ludmila MUCHOVÁ, Budete mými svědky: dialogické rozvijení křestanské identity ve světonázorově pluralitní společnosti - pedagogická výzva, Brno: Kartuziánské nakladatelství a vydavatelství, 2011, pp. 115-119.

15 Cf. Aleš OPATRNÝ, Pastorace v postmoderní společnosti, Kostelní Vydří: Karmelitánské nakladatelství, 2001 and Aleš OPATRNÝ, Cesty pastorace v pluralitní společnosti, Kostelní Vydří: Karmelitánské nakladatelství, 2006.

16 VEN, Practical theology..., pp. 92-93.

17 Cf. Rosino GIBELLINI, Teologické směry 20. století, Kostelní Vydří: Karmelitánské nakladatelství, 2011, pp. 365-394.

18 Cf. Michael MARTINEK, Ztracená generace? O duchovním dialogu mezi českou mládeží a katolickou církví, Svitavy: Trinitas, 2006.

19 Cf. part 5 of Handbuch der Pastoraltheologie. Karl RAHNER, Lexikon der Pastoraltheologie: Handbuch der Pastoraltheologie: praktische Theologie der Kirche in ihrer Gegenwart, Freiburg im Breisgau: Herder, 1972. 
to adopt social sciences and their methods. Van der Ven, however, notes that the relationship between theology and empirical sciences is not sufficiently theoretically defined in Rahner's manual of pastoral theology. For example, he does not consider the possible disadvantages of its concept. Van der Ven's objections to Rahner's conception of the relationship between empirical sciences and theology can be summarised as follows:

1. According to Rahner, theology is absolutely superior to empirical sciences, yet it depends entirely upon their research. Also, there is not enough research material (created by empirical sciences) for use in practical theology. The research of the ecclesial environment does not appeal to researchers in the social sciences. ${ }^{20}$ In addition, these theorists (who are not educated in theology) can deal with theological terms only with great difficulties, thus the theological interpretation of their results can be quite problematic.

2. It is not clear what kind of theological perspective should be used for the interpretation of research. Handbuch der Pastoraltheologie prefers the history of salvation. However, Van der Ven argues that this criterion is too abstract. In addition, he says, there is no explanation on how this measure should be linked to the specific problems and needs of the people in the Church. Can one find any other criteria in church practice and in the human experience of faith?

3. The two-step process (suggested by Rahner) seems to be problematic as well. This process works with completely different categories and thus it could be difficult to balance it.

What categories are used by the empirical sciences? As an example, I would like to present the categories from sociology. This science assumes a certain philosophy (or sociological theory), which then significantly influences the sociological perception and evaluation of reality. Due to the distinct differences amongst individual sociological perspectives, the view of structural functionalism was chosen as an example. ${ }^{21}$ According to this approach, the Church is based on steady social norms and non-formal sanctions and it has its role throughout society. Successful fulfilment of its function directs the society to deeper integration. As an element of society's structure, the Church is constantly influenced by its own social links. According to Talcott Parsons and his AGIL model, the Church has four subsystems or functions: adaptation, goals achievement, integration, and latent patterns maintenance. ${ }^{22}$ Adaptation involves adjusting to the options and providing resources from the environment. Achieving goals also means the streamlining of resources in order to achieve goals and set priorities. The Church (in order to be coherent and to be able to achieve the goals) regulates relationships within the system by norms. To make this work, it needs to motivate participants to perform the roles necessary for the system and also it needs a control mechanism to maintain tension in the system. At the higher level, that is, at the level of the social system as a whole, religion and churches fulfil the role of preserving the patterns. By changing

20 Van der Ven talks about the situation in the Netherlands. The situation in the Czech Republic is even worse. Sociology of religion (in the Czech Republic) is not in a satisfactory state. Zdeněk R. Nešpor even calls it not fully established. Cf. Zdeněk R. NEŠPOR, Ne/náboženské naděje intelektuálů: vývoj české sociologie náboženství v mezinárodním a interdisciplinárním kontextu, Dolní Břežany: Scriptorium, 2008, pp. 368-376. In addition to the regular population census (which yields statistical results on the decreasing number of believers in the largest Czech churches), EVS and ISSP surveys are regularly conducted. Analysis of quantitative research of religion in the Czech Republic was conducted, for example, by Dana Hamplová in her publication: Dana HAMPLOVÁ, Náboženství v české společnosti na prahu 3. tisíciletí, Praha: Karolinum, 2013. In the area of qualitative methods, the exceptions are two very good and detailed studies by J. Váně and B. Spalová: Jan VÁNĚ, Komunita jako nová naděje?: náboženské (ne)institucionalizované komunity $z$ pohledu sociologie náboženství, Plzeň: Západočeská univerzita v Plzni, 2012; and Barbora SPALOVÁ, Bưh ví, proč: studie pamětí a režimů moci $v$ křestanských církvích v severních Čechách, Brno: Centrum pro studium demokracie a kultury, 2012.

21 Processed in accordance with Émile DURKHEIM, Elementární formy náboženského života: systém totemismu v Austrálii, Praha: OIKOYMENH, 2002; Talcott PARSONS, Společnosti: vývojové a srovnávací hodnocení, Praha: Svoboda, 1971; and Daniel L. PALS, Osm teorií náboženství, Praha: ExOriente, 2015.

22 Cf. Zdeněk R. NEŠPOR - David VÁCLAVÍK, Příručka sociologie náboženství, Praha: Sociologické nakladatelství SLON, 2008 , p. 65. 
one element of a structure, the whole structure changes, including the church and its links. In the example of structural functionalism, the profound difference between the sociological and theological theories of the Church can be clearly demonstrated. Van der Ven is aware of this gap and calls for the change of approach. This change is offered by using the following models.

\section{The Interdisciplinary Model}

The fifth part of German pastoral theology's Lexikon der Pastoraltheologie (1972) endorses the interdisciplinarity between practical theology and social sciences and calls for the development of this approach. The interdisciplinarity model can be of two kinds:

1. The theologian is also a sociologist, or

2. Theologians and sociologists work together.

The fundamental advantage of this model comes through a constructive dialogue between the theological and empirical disciplines being really achieved, and the results of the jointly conducted studies are acceptable and relevant to both sides. Interdisciplinarity has been the dominant approach in the German environment recently. ${ }^{23}$ In our context, an example of the interdisciplinary approach could be the habilitation thesis written by Michal Kaplanek. He carried out a piece of qualitative research in the form of thematic conversations with converts. According to the results, he evaluated the motivation of young people entering the Catholic Church and proposes pastoral priorities regarding the subject. ${ }^{24}$ However, Van der Ven does not favour interdisciplinarity and sees it as a major problem. Theology and sociology are based on different paradigms and use different methods. Which of them will be (by the scientist theologian and sociologist) preferred? Will he fall into scientific confusion? When it comes to multi-expert collaboration, can a real balance be set and can a productive dialogue be led within the research group? Are theologians able to respect the sociological paradigm and, on the other hand, are sociologists able to acknowledge the theological paradigm? Are theologians able to bear the overwhelming criticism of sociologists and will sociologists listen to theologians, in spite of the fact that it was theology (and philosophy) which the social sciences wanted to be separated from? It seems that many sociologists have already clearly indicated the fact that they do not need theology at all. ${ }^{25}$

The attempts to establish a dialogue between theology and contemporary social sciences will end up with an uneven distribution of forces, no matter what anyone think about it. The reason is that social sciences do not need theology to do their work, whereas practical theology (at least in the interdisciplinary model) cannot exist without them. ${ }^{26}$

\section{The Model of Intradisciplinarity}

23 The interdisciplinary approach is used, for example, by P. M. Zuhlener, H. G. Zieberts and T. Faix. Zuhlener is a co-author of the EVS researches. H. G. Ziebertz viz. Hans-Georg ZIEBERTZ, Imagining God: empirical explorations from an international perspective, Münster: LIT, 2001.

24 For a shortened version of the habilitation thesis in German, cf. Michal KAPLÁNEK, Rozhodnutí mladého člověka nechat se pokřtít v katolické církvi, in: Konverze a konvertité: sborník z mezioborového semináře o problematice náboženského obrácení, ed. Ivana NOBLE - Jiří HANUŠ, Brno: Centrum pro studium demokracie a kultury, 2009, pp. 81-110.

25 Cf., for example, Peter L. BERGER, Vzdálená sláva: hledání víry ve věku lehkověrnosti, Brno: Barrister \& Principal, 1997.

26 VEN, Practical theology..., p. 100. 
Van der Ven considers the model of intradisciplinarity to be the best solution for the relationship between practical theology and social sciences. Intradisciplinarity implies the use of methods and techniques of one discipline in another, which is common in sciences especially during their development. Is not theology a science that has always responded to methodological trends during the time or even (at certain times) dictated them? Is not the ideal time to adopt empirical methods now? However, will theology still remain theology? Van der Ven implies that the answer is 'yes' and he gives several reasons for his claim. The use of empirical methods is adequate because the main object of theology is not God himself, but our human experience with him. ${ }^{27}$ If God was a direct object of theology, the use of empirical methods would be impossible. The revealed God is, in Van der Ven's view, only partly recognisable through faith and through the human experience with Him. This experience is both individual and social (the experience of the church community) and as such it is (in some way) reflected in the tradition of the church. It is acceptable to examine this experience empirically because it is all human. At the same time, other methods (from other branches of theology) can be used. Theology is not united in the question of methods. The methods are grouped into individual methodological families that share the same premises and argumentations. The classification of theological methods itself becomes a complex problem for their large number. R. Haight even speaks of the typology of the typology of theological methods. ${ }^{28}$ It is therefore up to the subjective judgment of the theologian which methods he decides to use for his work. Van der Ven prefers the intradisciplinary model because (according to him) it solves the problems of previous models. R. Ganzevoort argues, however, that this model can lead to the isolation of practical theology (like in the case of the monodisciplinary model) because it does not engage in dialogue with the social sciences. ${ }^{29}$

Van der Ven considers practical theology to be a hermeneutic-communicative practice that seeks to fill the gap between tradition and the present by constant communication. There is a significant influence of Habermas' ethics which is corrected by the concept of the Kingdom of God. ${ }^{30}$ Tradition can be investigated by a literary-critical or historical method. To explore the present, empirical methods seem to be ideal. These have been specifically created as an instrument of social sciences in order to explore man and his experience in the world. Again, it must be reiterated that this does not represent any problem for practical theology. The only question is how it will handle the methods. Empirical methods are a challenge for other fields of theology as well. For example, the theological notions sensus fidelium and consensus fidelium ${ }^{31}$ (which are directly offered for empirical exploration) can serve as an example. The believer's sense for matters of faith is indeed a beautiful theological concept, but what does the believer really believe in? Does he or she believe in the traditional doctrine of the Church, or does he or she discover new theological ideas in his or her own Christian practice? Perhaps theological concepts and theories emerging from this particular type of exploration will be more understandable for believers, and will bring academic theology written 'on the table' to a wider circle of believers. But are theological concepts

27 For example, Ivana NOBLE, Po božích stopách: teologie jako interpretace náboženské zkušenosti, Brno: Centrum pro studium demokracie a kultury, 2004; Leonardo BOFF and Clodovis BOFF, Introducing liberation theology, London: Burns \& Oates, 2000; also, Paul TILLICH, Lidské tázáni po nepodmíněném, Brno: 3K, 1997.

28 Cf. Roger HAIGHT, Critical Witness: The Question of Method, in: Faithful Witness. Foundations of Theology for Today's Church, eds. Leo J. O’DONOVAN - T. Howland SANKS, New York: Crossroad, 1989, p. 188.

29 Cf. R. Ruard GANZEVOORT, Van der Ven's Empirical/Practical Theology, in: ed. C. A. M. HERMANS and Mary Elizabeth MOORE, Hermeneutics and empirical research in practical theology: the contribution of empirical theology by Johannes A. van der Ven, Boston: Brill, 2004, p. 63.

30 Cf. VEN, Practical theology..., pp. 59-73 and Richard R. OSMER, Johannes van der Ven's Contribution to the New Consensus in Practical Theology, p. 155.

31 LG 12. 
and theories measurable? Van der Ven says 'yes'. Theology traditionally uses analogies and models to interpret its terms. These terms then can be used in research by using careful operationalisation. Van der Ven prefers the mixed form of research and suggests a method of an empirical -theological circle, which involves problem and goal determination, induction, deduction, testing itself, and the evaluation of results. The results of this research are not theological theories. They are rather a contribution to the hermeneutic communicative practice of the Church. They are an attempt to understand and improve the Church itself.

Attempts were made to compare Van der Ven's empirical-theological circle with the pastoral circle, a concept emerging from the theology of liberation in the Latin-American environment. The pastoral circle is an improved concept of Cardan's method. His method (to see-judge-act) was accepted in the Roman Catholic tradition and applied in the encyclical letter Mater et Magistra. ${ }^{32}$ In the pastoral circle, the individual steps are as follows: experience (to see), social analysis and theological reflection including prayer (to judge), and pastoral acting (to act). ${ }^{33}$ In the British environment (in their practical theology), the pastoral circle is used by P. Ballard and J. Pritchard. ${ }^{34}$ Specifically their concept is compared with Van der Ven's empirical-theological circle by M. J. Cartledge. ${ }^{35}$ However, it is a comparison of something incomparable. The pastoral circle is, mainly, a practical tool for solving problems in the pastoral ministry of the Church (for example, in the Church community). It does not operate with a sophisticated empirical methodology and does not even need it. The analysis takes the form of discussion and prayer of the participants. The Van der Ven method of the empirical-theological circle is (primarily) a methodological guide for the performance of empirical-theological research in practical theology; it is not a pastoral aid for the community.

\section{In a Quantitative or Qualitative Way?}

Van der Ven's method of an empirical-theological circle can be classified as a mixed approach because it works with both quantitative and qualitative methods. It contains both induction and deduction. However, in empirical theology and in its different forms, these approaches are used differently. What is the difference between them? What results do they lead to? First, it is necessary to define both approaches in the paradigm of empirical methodology, and then to present the situation in the theoretical field of empirical theology.

\section{The Field of Social Sciences and the Humanities}

In many ways, quantitative approaches used for the research in social sciences copy the methodology of natural sciences. Human behaviour is supposed to be measurable and predictable to some extent. Quantitative research employs random selections, experiments, and a highly structured data collection using tests, questionnaires, or observations. Created concepts are obtained by measuring. Then we analyse obtained data using statistical methods. The aim is to investigate, describe, or verify the validity of our ideas about the observed variables. ${ }^{36}$

32 Viz. Mater et Magistra, para. 236.

33 Cf. Joe HOLLAND - Petr L. HENRIOT, Social analysis: linking faith and justice, Maryknoll, N.Y.: Orbis Books, 1983.

34 Paul BALLARD - John PRITCHARD, Practical Theology in Action: Christian Thinking in the Service of the Chruch and Society, London: SPCK, 1996.

35 Cf. Mark J. CARTLEDGE, Practical Tehology and Empirical Identity, EuroJTh, 1998, 7:1, pp. 37-44. Viz. https://biblicalstudies.org.uk/ pdf/ejt/07-1_037.pdf.

36 Jan HENDL, Kvalitativní výzkum: základní teorie, metody a aplikace, Praha: Portál, 2012, p. 44. 
Quantitative research can be simply characterised as a verification of hypotheses that are deduced from a certain theory by a researcher. Operationalisation is used to convert hypotheses into measurable forms. Measurements usually take the form of a test or a questionnaire. In the end, the hypotheses are tested, and the result is related back to the theory. ${ }^{37}$ The representability of the selected sample, its reliability and its validity are important. The results of such research can be generalised to the population and, also, they are relatively independent of the researcher and provide quite accurate data.

Qualitative research was initially perceived as a kind of complement to the previous approach. At present, it is more of an equal partner. It uses mostly the inductive method, and there is more than one way for qualitative research practice..$^{38}$ Mostly (however) at the beginning of this kind of research, there is a topic and research question, according to which the researcher searches and analyses all the information related to the issue. The researcher often works in the field and is a direct part of the research. Research has a long-lasting character: it ideally delves as deeply as possible. Data analysis and its collection are carried out at the same time. The results of such research cannot be generalised, they are rather a probe into the chosen problem and help to understand its theory. Given the goal of such research, reliability is not as important as it is with quantitative research. On the other hand, validity is significantly higher.

At present, both approaches are considered to be complementary to each other. Mixed types of research are often carried out using both techniques. Still, there are scientists who consider the qualitative approach to be less scientific as well as researchers who (on the contrary) disapprove of the quantitative approach as unsuitable for the exploration of people. ${ }^{39}$ What is the situation in empirical theology?

\section{The Field of Empirical Theology}

In empirical theology, as such, there are quantitative, qualitative and mixed types of research. At first (in the same way as in sociology) quantitative research prevailed, ${ }^{40}$ and the second approach later expanded. Qualitative approaches are the most often ethnographic, or they take the form of settled theory. ${ }^{41}$ Van der Ven then prefers the mixed method and gives it the form of the empirical-theological circle mentioned above. The quantitative method contains accurate data, its results can be generalised, and findings can represent a real challenge for theology, precisely because of its representativeness. If the census results show the falling numbers of church members or the EVS researches show a lack of knowledge of Christian values (even among the 'on paper' members of the Church), it is a problem for the Church that needs to be addressed. However, quantitative research cannot go deeper. It will not tell why people are leaving the Church, to where they are leaving, and what they really think about the Church. The depths of faith cannot be quantified. At

37 Cf. HENDL, Kvalitativní výzkum..., p. 44.

38 J. Hendl uses a classification of qualitative approaches made by L. Spencer. Spencer mentions individual traditions of qualitative research that have evolved in various social sciences or humanities. These are: ethnography, phenomenology/ethnomethodology, conversational analysis, discourse analysis, protocol analysis, anchoring, constructivism, critical theory and ecological psychology. At the same time, however, he warns that new approaches are still emerging. See Jan HENDL, Kvalitativní výzkum..., p. 52.

39 Cf. HENDL, Kvalitativní výzkum..., pp. 54-62.

40 Viz., for example, one of the first collective publications in the area of empirical theology, by H. G. Ziebertz. It is an attempt to introduce the already realised quantitative research in an international perspective. In this case, the term 'empirical theology' is understood much more widely than in Van der Ven's approach. It is the sociological examination of theological questions as well. Viz. Hans-Georg ZIEBERTZ, Imagining God: empirical explorations from an international perspective, Münster: LIT, 2001.

41 Cf. Peter NÁKAČKA, Grounded theory a možnosti jej využitia v oblasti praktickej teologie, Teologický časopis: Fórum pro krestanský dialóg 1/2016, p. 83. 
the same time, there is not enough space for the impact of theology in the research. The researcher strives for the greatest possible detachment and objectivity, his role influences only the selection of the topic at the most, and the research is usually carried out without immediate interaction with the studied sample. It can be assumed that a researcher needs to be a theologian only for the theologically correct operationalisation of a hypothesis and for the analysis of results. A quantitative approach can therefore work very well in a multidisciplinary and interdisciplinary model. I believe that theology requires a combination of qualitative and quantitative approaches. It is (by its nature) open to a researcher who professes his or her own philosophy or faith. There is often a direct interaction between the researcher and the researched one. Therefore, it seems to be more appropriate for use in theology. However, its conclusions can only be generalised with great caution and it can only be realised at a micro level. Thus, it seems that (even in empirical theology) one approach does not take place without the other and each of them needs to be balanced. What do empirical theologians call it themselves? First of all, we need to point out the relationship between quantitative and qualitative approaches. An analysis of Jaco S. Dreyer's approach will serve this purpose. Then we will introduce ethnography as a specific empirical-theological approach in the concept of Pete Ward and his colleagues from the Ecclesiology and Ethnography platform. ${ }^{42}$

\section{Detachment or Participation?}

An interesting perspective on the relationship between quantitative and qualitative approaches is brought by Jaco S. Dreyer. ${ }^{43}$ He points to the prevailing dichotomy between the two approaches. To overcome this contradiction, he uses Paul Ricoeur's hermeneutics. Ricoeur, in his essay on the relationship between science and ideology, ${ }^{44}$ points out that if we want to understand society and its function (its relationships, cultural tradition and history), there is a dialectic tension between our relative autonomy (or detachment) towards those issues and our participation (at the same time) which cannot be omitted. If we ultimately want to minimize ideological influences in our search for this understanding, it is necessary to use this tension as part of the hermeneutic quest for truth. Dreyer accepts this assumption and relates it to the main empirical approaches. He characterises quantitative research specifically by one's personal detachment and qualitative participation.

A scientist must therefore sink into the world of those he or she is examining (participation) so that their voices are not overridden by scientific interpretation. This necessity assumes a qualitative approach. On the other hand, a part of the goal is to eliminate the ideological interpretations of examined people which can be done only with a sense of detachment given by the quantitative approach. It represents the exact opposite approach. ${ }^{45}$

42 Since 2007, The Ecclesiology and Ethnography Platform and its members (the academics) have been dedicated to the theological and empirical study of Christian churches in an ecumenical spirit. Viz: http://www.ecclesiologyandethnography. $\mathrm{com} /$.

43 Viz. Jaco S. DEYRER, Establishing truth from participation and distanciation in empirical theology, in: Empirical theology in texts and tables: qualitative, quantitative and comparative perspectives, eds. Leslie J. FRANCIS, Mandy ROBBINS and Jeff ASTLEY, Boston: Brill, 2009, pp. 3-25.

44 Paul RICOEUR, From Text to Action: essays in hermeneutics II, London: Athlone Press, 1991, pp. 258-269, cited in accordance with DEYRER, Establishing..., pp. 7-8.

45 DEYRER, Establishing..., p. 9. 
In empirical research, the term 'participation' refers to our situation in the world, to our encounter with others and their own past, and prevents us from forcibly pushing the experience of others into pre-prepared concepts and schemes. Detachment is the foundation of a scientific approach and involves the pursuit of objectivity, critical thinking, conceptualisation, comparison, and others. Every researcher must be able to critically assess his or her own cultural, economic, social and political positions, which he or she can achieve just by looking at it with a sense of detachment. Dreyer argues that a certain degree of detachment and participation is present in both approaches, so they do not represent diametrically different ways of understanding reality. The tension between detachment and participation protects (in Ricoeur's view of hermeneutics) science in order to not become an ideology. In a quantitative approach, particular attention should be paid to the fact that the detachment should not prevail over participation. In a qualitative approach on the other hand, it should be the exact opposite. The fruitful tension between the two contributes to true understanding. This tension will ensure the art of reflexivity, as characterised by Pierre Bourdieu ${ }^{46}$ It is necessary to be able to reflect upon our own prejudices, our own scientific community and its methods. This is a lifetime work for the empirical theologian. The term 'reflexivity' is also the basis of the practical theology of P. Ward. This theologian-researcher reflects on his personal, social and cultural contexts in his research. These contexts influence not only what is being investigated, but also how his research is performed ${ }^{47}$ Reflexivity is required (to a large extent) by the ethnographic approach that we will now focus on.

\section{Ethnography as Reflective Theology}

Ethnography belongs to qualitative research techniques and assumes the direct participation of the observer on the exploration of phenomena. It has traditionally been used to gain the overall picture of a particular social group; originally (for example), it observed tribes living in a remote location in the world. It uses predominantly different types of observations and interviews with the individuals or groups surveyed. The perspectives of group members, the content and forms of their thinking, their interaction, and their social practices are explored. It is a description of a particular group as a whole, including its parts and the relationships between them. ${ }^{48}$ At the present time, the concept of ethnography includes a number of approaches from different disciplines. For the concept, the following elements are important: participation, nesting, reflection, reflexivity, representation, detailed description, understanding of the ethical principles of the group, empowerment and understanding, as such. ${ }^{49}$ At first glance, ethnography appears to be a suitable tool for theology, especially for the examination of Church practice. Pete Ward believes that if we really want to understand the Church, we must admit the fact that it is both a theological and a social-cultural entity. It is therefore necessary to use both theological and sociological means to explore this reality.

It requires constant interaction between theories and principles derived from theological tradition and the receptive and participating observation of individual aspects of the situa-

46 Cf. Pierre BOURDIEU, Science of Science and Reflexivity, Chigaco: University of Chicago Press, 2004, cited in accordance with DEYRER, Establishing truth from participation and distanciation in empirical theology, pp. 20-23.

47 Pete WARD, Participation and Mediation: A Practical Theology for the Liquid Church, London: SCM Press, 2008, p. 3.

48 Cf. HENDL, Kvalitativní výzkum..., pp. 115-116.

49 Cf. Julie SCOTT-JONES - Sal WATT, Enthography: Principles into Practice, London: Routledge, 2007, p. 1, cited in accordance with Pete WARD, Perspectives on ecclesiology and ethnography, Grand Rapids, Mich.: W. B. Eerdmans Pub. Co., 2012, p. 6. 
tion in Church. Theological generalizations will be influenced by this observation, using methods of social and cultural research, still this observation is basically theological..$^{50}$

The use of empirical methods can be justified purely theologically. Paul S. Fiddes argues using the Trinity. ${ }^{51}$ According to him, theology assumes that we live in a world where the Triune God reveals himself. This God cannot be objectively observed as the other things in the world are. He is known in a different way, more precisely by participating in his love. By this love, each Divine Person in the Trinity is linked to the others. When we engage ourselves in a community of reciprocity and fulfilling relationships that are deeper and richer than we could imagine (or than we could create ourselves) we recognise God of the Trinity deeply. Outside of God there is nothing. He is fully manifested in the world, and we can recognise Him only through our world. In the field of ecclesiology (or practical theology), this is twice true. In this field, God's action is indeed presumed. But we must reject the legacy of rationalism that distinguishes subject and object in the world. We must explore and come to know (by our participation), which is the essence of the ethnographic approach.

John Swinton also advocates for ethnography. ${ }^{52} \mathrm{He}$, like Van der Ven, refuses to use sociological methods to explore theological phenomena in the same way as sociologists. He argues that these methods have a hidden non-theological perspective in the background. For ethnography, mainly phenomenology or naturalism represent the right perspective. ${ }^{53}$ However, the main research tool in this approach is the researcher himself. He is also a theologian and probably also a member of the church he is going to examine. Why should he look at it as a psychologist or sociologist? Apart from the observation process, the process of interpretation is the most important for ethnography. We can perceive the latter as an attempt for the maximum objectivity which seems impossible. Or, we can perceive it as Hans G. Gadamer who (in his hermeneutics) assumes pre-understanding. Subjective and objective are combined together in one cultural and social context. ${ }^{54} \mathrm{~A}$ theologian can include his theology in ethnography both in observation and interpretation, which requires the (several times mentioned) reflexivity. He argues that it is 'a way of cognition which (creatively and efficiently) involves the scientist in the process of interpreting. It recognizes the fact that it is impossible for him to stand apart from this process. ${ }^{55}$ Every exploration is, to some degree, autobiographical. Swinton further argues that sociologists can, of course, examine the Church from their perspective. The correlation of perspectives is desirable, but (most of the time) only theologians desire it. The same is true of Van der Ven in his critique of the interdisciplinary model. ${ }^{56}$ However, a theologian cannot examine the church he lives in as a sociologist. It would not be effective or trustworthy. He can only examine it as a theologian, and in his interpretation he can recognise it. The outcome of such an examination will surely be various interpretations of the church environment, depending on the denomination of the researcher. This (again) will not be new in the theological tradition. However, it is also necessary for him or her to step out before a non-theologian audience who can reject his or her outcome. In this sense, such an outcome may also become a challenge to his or her own reflexivity.

50 Pete WARD, Perspectives on ecclesiology and ethnography, p. 2.

51 Paul S. FIDDES, Ecclesiology and Etnography: Two disciplines, two worlds?, in: Pete WARD, Perspectives on ecclesiology and ethnography, pp. 13-36.

52 Cf. John SWINTON, Where is your Church?, in: Pete WARD, Perspectives on ecclesiology and ethnography, pp. 71-92.

53 A detailed analysis of these sociological perspectives is processed by Swinton in: John SWINTON and Harriet MOWATT, Practical Theology and Qualitative Research, 2nd edition, London: SCM, 2016.

54 Cf. Hans G. GADAMER, Truth and Method, New York: Crossroad, 1989, p. 273, cited in accordance with SWINTON, Where is..., p. 82.

55 Cf. SWINTON, Where is..., p. 84.

56 Cf. VEN, Practical theology..., p. 100. 


\section{Conclusion}

In this article I have tried to prove that theology needs (among other things) empirical methods to reflect human faith in the world and (in a certain sense) to speak about God as well. Theology cannot remain only on the horizon of existential rationality, although it is undoubtedly based on it. It can and should be investigated in the intellectual horizon also. Since the publication of the German post-conciliar Handbuch der Pastoraltheologie, there has been no doubt (in practical theology) about the importance of using empirical methods in theology. However, there is no unambiguous approach to applying these methods. Van der Ven has created paradigmatic models using various approaches to empirical techniques. We can meet multidisciplinary research (when theologians attempt to theologically interpret the results of social sciences research) or the interdisciplinary (where collaboration between social scientists and theologians takes place). Van der Ven, however, considers both approaches to be problematic because of the dominance of social sciences over theology. He proposes an intradisciplinary model as a solution. In this model, the theologian adopts empirical methods and uses them as a theologian, which can be well realised in qualitative research techniques. These techniques represent an inductive basis for further investigation. This may later be quantitative (deductive) also. In practical theology it is important to use both techniques. We need both the depth (that can only be achieved in qualitative terms) and the representativeness (that a quantitative approach can provide). Van der Ven proposes the method of an empirical-theological circle as a mixed technique combining both approaches. A specific qualitative method is represented by ethnography, where the observer is directly involved in observed phenomena. This particular method seems to be an ideal tool for theologians who wish to explore the church environment. These explorations may be an impulse for theologians to revise their own theology and, foremost, they require reflexivity. It may also pose a challenge to systematic theology. F. Štěch, according to P. Ward, claims that every theology is auto(theo)biographical:

auto(theo)biographic theology is not just a study and a critical reflection of the sources of Christian faith, it is also a walk through the countryside, washing dishes, helping a neighbour, taking children to school, praying, chopping wood for the winter, the joy of coming spring, comforting of one's partner, dinner with friends, a concert visit, or taking care of trash..$^{57}$

This is because theology is also life in the present world in which God reveals himself. I believe that every 'auto(theo)biography' also needs a reflected experience of the church community, which can be obtained first and foremost by the ethnographic approach. How will theology be transformed when systematic theologians (before they sit down behind their desks) visit the community of believers and question the quality of their present experience of faith in the world they live in, and when they observe these people? Will not theology become more credible then? 


\title{
The Possibilities of Using Empirical Methods in (Practical) Theology
}

\begin{abstract}
Traditionally, the thinking horizon of theology seems to be different than the one of the social sciences. Theology and the social sciences also use different methods. However, since the Second Vatican Council, the methods of the social sciences, the empirical methods, have been gradually implemented into practical theology. However, there exists not only one way of carrying it out. The paper deals with the possibility of using empirical methods in (practical) theology. Johannes van der Ven's models of relationships between these methods and practical theology are described and analysed. Intradisciplinarity is granted as the most suitable model for both practical and systematic theology. The most appropriate method for theology within the model of intradisciplinarity is the qualitative technique that puts great importance on the scientist himself. This is specifically the case with the ethnographic approach. This technique allows the theologian to remain the theologian and use the reflected religious experience of other believers as a starting point of his theological reflection.
\end{abstract}

Key words: practical theology, empirical methods, empirical theology, intradisciplinarity, qualitative approach, ethnography

\section{Author contact}

\section{Jana Šídlová MA}

University of South Bohemia in České Budějovice Faculty of Theology, Department of Education Kněžská 8, 37001 České Budějovice sidloj00@tf.jcu.cz 